professionalization of the foreign language learning process]. Magazine Kyiv State Linguistic University. Ser.: Pedagogy and Psychology. Vol. 3, pp. 179-184. [in Ukrainian].

2. Bezukladnykov, K. A. (2007). Profescionalnyiy portfolio kak sredstvo formirovaniya profescionalnoy kompetentnosti buduschego uchitelya inostrannogo yazyika [Professional teachers' portfolio as means of formation the professional competence the future teachers of foreign languages]. Foreign languages at school. No. 6, pp. 66-70.[in Ukrainian].

3. Mysechko, O. Ye. (2010). Aktualni pytannia formuvannia profesiinoi maisternosti vchytelia $v$ umovakh instytutiv fakultetiv inozemnykh mov v Ukraini (druha polovyna XX st.) [Actual questions of formation of teacher's professional skills in the Institutes. Foreign languages departments in Ukraine (second half of the twentieth century)]. Foreign languages in the educational institutions. No. 4, pp.121-124]. [in Ukrainian].

4. Mysechko, O. Ye. (2002). Rozvytok kulturolohichnoho komponentu $v$ zmisti profesiinoi pidhotovky maibutnoho vchytelia inozemnoi movy [Development of culturological component in the content of professional training of future foreign languages teacher]. Magazine Zhytomyr Ivan Franko State University. pp. 94-96. [in Ukrainian].

5. Petrov, O. M. (2008). Linhvosotsiokulturna kompetentnist maibutnikh vchyteliv inozemnykh mov yak pedahohichne poniattia [Linguistic and Socio-cultural competence of future foreign language teachers as pedagogical concept]. Native school. No. 6, pp. 52-54. [in Ukrainian].

6. Sukhomlynska, O. V. (2003). Do pytannia pro rozvytok zmistu zahalnoi serednoi osvity [On the issue of developing the content of general secondary education]. Magazine Chernivtsi State University. pp. 161-169. [in Ukrainian].

7. Sukhomlynska, O. V. (2007). Metodolohiia doslidzhennia istoryko-pedahohichnykh realii druhoi polovyny XX stolittia [The Methodology of research the historic-pedagogical realities the half of XX century]. The Way of education. No. 4, pp. 6-12. [in Ukrainian].

Стаття надійшла до редакції 29.01.2019

УДК 377.314 .6

DOI:

Наталія Божко, кандидат педагогічних наук, доцент кафедри педагогіки, методики та менеджменту освіти

Украӥнської інженерно-педагогічної академії

\title{
ІНТЕГРОВАНЕПРОЕКТНО-ТЕМАТИЧНЕНАВЧАННЯ КВАЛФФКОВАНИХРОБІТНИКІВ
}

У статті розглянуто один із напрямів реформування системи освіти Украӥни - впровадження інтегрованого навчання в різних типах навчальних закладів. Охарактеризовано один з видів інтегрованого навчання - інтегроване проектно-тематичне навчання, передумови його виникнення та можливості застосування. Визначені особливості організачії інтегрованого проектно-тематичного навчання 8 загальноосвітньому навчальному закладі та можливостей його застосування у закладах професійної освіти в процесі підготовки кваліфікованих робітників. Наведено приклади можливих інтегрованих тематичних проектів.

Ключові слова: реформування; система освіти; інтеграція; інтегроване навчання; інтегроване проектно-тематичне навчання; інтегрований тематичний проект; професійна освіта, кваліфікований робітник.

Puc.1.Jim. 13.

Nataliya Bozhko, Ph.D.(Pedagogy), Associate Professor of the Pedagogics, Methodology and Management of Education Department Ukrainian Engineering Pedagogic Academy

\section{INTEGRATED PROJECT AND THEMATIC TRAINING OF QUALIFIED EMPLOYEES}

The article deals with one of the directions of reforming the education system of Ukraine - the introduction of integrated education into various types of educational institutions. The definition of "integrated training" is given, the conditions listed, which the integration process must meet.

One of the types of integrated training is characterized - integrated design and thematic training, the preconditions for its emergence. The listed positions of the leading teachers and psychologists of the world, which formed the basis of modern integrated design and thematic training. The indicated programs for the study of students in general education institutions, the future teachers in higher education institutions and the improvement of professional qualifications of working teachers, based on the idea of integrated training.

The peculiarities of organization of integrated design-thematic training in the general educational institution are characterized. The definition of the concepts "horizontal" and "vertical" integration is given. As an example, an integrated thematic project for a comprehensive educational institution on the topic "Tree of the school yard", an integration function in which the discipline "Natural science" and its notion "trees" perform. Listed academic 


\section{ІНТЕГРОВАНЕ ПРОЕКТНО-ТЕМАТИЧНЕ НАВЧАННЯКВАЛІФІКОВАНИХ РОБІТНИКІВ}

disciplines whose content is integrated in the implementation of this project, as well as knowledge and skills that are formed in the students.

The peculiarities of organization of the training process in the system of vocational education in the present conditions and the possibility of applying integrated design and thematic training in the institutions of vocational education in the process of preparation of skilled workers are considered.

An example of an integrated thematic project for the establishment of vocational education in the preparation of skilled workers from the profession "Tailor" is given $2-3$ categories according to the standards of the new generation. The integration function of the system of vocational education is carried out by the industrial training, the disciplines whose content is to be integrated in the framework of this project are technology, equipment, material science, economics, information technology, special drawing, labor protection. The advantages of integrated designthematic training are defined.

Keywords: reforming; an education system; an integration; integrated training; integrated design-thematic training; integrated thematic project; a vocational education, a skilled worker.

П остановка проблеми у загальному вигляді. Сучасна освітня діяльність спрямована на підвищення загальнокультурного рівня випускника закладу освіти. Ключовим моментом педагогічної взаємодії $є$ розвиток можливостей учнів, формування їх професійно значущих компетенцій, підготовка до майбутньої життєдіяльності. Але в сучасній педагогічній теорії та практиці спостерігається розбіжність у поглядах на вирішення цієї проблеми.

В першу чергу, далеко не всі педагоги ставлять формування вміння учнів знаходити вихід в життєвих ситуаціях на перше місце, більш значущим вони вважають наявність знань зі свого предмету, а не вміння ними користуватися. На практиці часто можна спостерігати, як ті, учні, які добре знають предмет, губляться, якщо свої знання потрібно застосовувати на практиці. I навпаки, учень проявляє себе, якщо йому пропонують вирішити якусь практичну задачу, 3 якою на вузькоспеціальному предметі він напевно не впорався б, але, маючи можливість розглянути їі як приклад з практики, легко знаходить вихід із ситуації.

По-друге, не існує однозначної думки з приводу професійної значущості для учня того чи іншого знання або вміння. Одним із способів вирішення цього питання має стати інтегроване навчання. Інтегроване навчання значно оновлює зміст освіти та спрямовано на вирішення основних завдань освіти - підвищення їі доступності, якості та ефективності; крім того, для учня - це можливість по-новомуподивитися на свої здібності та оцінити себе в процесі навчання.

Інтегроване навчання (адаптовано 3 "Natural Curiosity: A Resource for Teachers" University of Toronto OISE) - це навчання, яке грунтується на комплексному підході. Освіта розглядається через призму загальної картини, а не ділиться на окремі дисципліни. Предметні межі зникають, коли педагоги заохочують учнів робити зв’ язок між дисциплінами й спиратися на знання i навички 3 кількох предметних областей в рамках певного тематичного проекту (основної форми організації навчання у новій українській школі). 3'являється так зване інтегроване проектнотематичне навчання [7].

Аналіз основних досліджень та публікацій, в яких започатковано розв'язання даної проблеми. Ідея проектно-тематичного (інтегрованого) навчання не $\epsilon$ новою. Так у $60-70$-ті роки ХХ ст. в педагогічних системах США та Західної Європи був проведений критичний аналіз діючих на той час навчальних програм, якими були незадоволені i вчителі, i батьки, і учні. Результатами такого аналізу стали розробки нових освітніх концепцій. Однією 3 яких була саме ідея проектнотематичного (інтегрованого) навчання для дітей раннього віку, в якій відображені погляди багатьох прогресивних педагогів і психологів світу: Дж. Дьюї, Ж. Піаже, Л. Виготського, Дж. Брудера, Г. Уеллса, Д. Колба, інших зарубіжних та вітчизняних учених [2].

Особливе значення для формування системи проектно-тематичного навчання мають:

- положення Дж. Дьюї, який підкреслював, що навчальна програма не повинна бути серією пізнавальних дисциплін, ізольованих одна від одної, а тим більше від повсякденного життя учнів; тема за темою, педагог заповнює дитину не знаннями в прямому значенні цього слова, а устремлінням пізнавати світ і ніколи не зупинятися на цьому [10];

- висновки Ж.Піаже, який висунув ідею освітньої практики, тобто конструювання знань дітей через їх практичні дії [9];

- положення Л. Виготського про зону наближеного розвитку дітей, що дозволяє при проектно-тематичному підході планувати навчально-виховний процес таким чином, щоб передбачувати потреби розвитку i реальні можливості кожної дитини [3];

- дослідження Г. Уеллса, який припустив, що кооперативний, або спільний спосіб навчання є найбільш продуктивним в умовах навчального процесу, орієнтованого на інтереси дітей. 
Партнерство педагога і дитини реалізується в такому груповому товаристві учнів, де педагог, як більш знаючий і досвідчений із партнерів, організовує педагогічну взаємодію за типом майстерні [2].

Таким чином, проектно-тематичне навчання - це педагогічна технологія, орієнтована на глибоке, інтенсивне та тривале вивчення учнями (спільно $з$ дорослими) певної (визначеної) проблеми або питання, що планомірно призводить до формування у дитини нових форм пізнання, поведінки і діяльності, іï повноцінного психічного та фізичного розвитку [6].

Перелічені вище положення лягли в основу:

- міжнародного освітнього проекту “Крок за кроком”, в реалізації якого взяли участь 23 країни світу. В Україні цей проект був апробований і адаптований до національного змісту шляхом всеукраїнського педагогічного експерименту під назвою "Особистістно-зорієнтована модель неперервної освіти гуманістичного типу “Крок за кроком” для дітей віком від 6 до 10 років”, охопив 53 навчальні заклади різного типу 7-ми регіонів. За висновками експертної комісії Міністерства освіти і науки України, програма "Крок за кроком" рекомендована до запровадження у загальноосвітніх навчальних закладах України;

- програму навчальної дисципліни "Проектна діяльність у навчальних закладах" для підготовки магістрів зі спеціальності 013 "Початкова освіта", серед переліку тем якої є "Інтегроване тематичнопроектне навчання";

- типової програми підвищення кваліфікації вчителів загальноосвітніх шкіл, що затверджена наказом МОН, серед переліку модулів якої $є$ “Інтегроване навчання".

Згідно з новим законодавством стосовно реформування системи освіти в Україні початок інтегрованого проектно-тематичного навчання вже покладено у початковій школі, що надасть можливість застосовувати його на наступних рівнях освіти.

Мета статті полягає у визначенні особливостей організації інтегрованого проектнотематичного навчання в загальноосвітньому навчальному закладі та можливостей його застосування у закладах професійної освіти в процесі підготовки кваліфікованих робітників.

Виклад основного матеріалу. Ідея інтеграції в освіті є значним здобутком дидактики, оскільки за умови їі успішного методичного впровадження реалізується мета якісної освіти. Тому інтеграція як вимога об'єднання в ціле компонентів об'єктів навчання $\epsilon$ необхідним дидактичним засобом, за допомогою якого уможливлюється створення в учнів цілісного уявлення про об'єкт, що вивчається, формується міжпредметна компетентність [5].

Процес інтеграції вимагас виконання певних умов [1]:

- об'єкти дослідження повинні бути однакові або досить близькі (тоді вони досліджуються з різних сторін, використовуючи навчальний матеріал різних дисциплін);

- у навчальних предметах повинні використовуватися однакові або близькі методи дослідження предметів та явищ (тоді $\epsilon$ можливість демонструвати спосіб пізнання дійсності на прикладах з різних предметів);

- те, що пізнається, повинно підпорядковуватися загальним закономірностям, які вивчаються на уроці (тобто узагальнення навчального матеріалу 3 різних навчальних дисциплін сприяє пізнанню більш складної системи)

Інтеграція навчального матеріалу 3 різних навчальних предметів відбувається, як правило, чи навколо певного об'єкту чи явища довкілля, або для розв'язання проблеми міжпредметного характеру, або для створення творчого продукту.

Інтеграція може бути [5]:

- горизонтальною - здійснюється тоді, коли поняття, що входять до складу навчальних дисциплін між якими існують інтеграційні зв'язки вивчаються відірвано в часі (наприклад, впродовж тижня, місяця);

- вертикальною - здійснюється тоді, коли поняття, що входять до складу навчальних дисциплін між якими існують інтеграційні зв'язки вивчаються в близьких часових межах (впродовж одного уроку, одного дня).

Тобто навчання в загальноосвітньому закладі окрім традиційного може бути інтегрованим та інтегрованим проектно-тематичним (коли інтеграція навчального матеріалу з різних навчальних предметів відбувається в процесі виконання певного тематичного проекту).

Існує багато літератури та наукових досліджень стосовно методу проектів, типів проектів, проектної діяльності, етапів її організації тощо. Наведемо стислий приклад інтегрованого тематичного проекту для загальноосвітнього закладу на тему “Дерева шкільного подвір'я”. Інтеграційну функцію в даному випадку виконує дисципліна "Природознавство" та її поняття “дерева”. Для того, щоб учні змогли вивчити цю тему на практиці, пропонується вивчати дерева не взагалі, а ті, що є на шкільному подвір'ї. Кінцевим результатом (оскільки результат роботи над проектом його передбачає) повинна стати “Карта дерев шкільного подвір'я”. Для того щоб 


\section{ІНТЕГРОВАНЕПРОЕКТНО-ТЕМАТИЧНЕ НАВЧАННЯКВАЛІФІКОВАНИХ РОБІТНИКІВ}

створити в учнів цілісне уявлення про об'єкт, що вивчається, відбувається інтеграція навчального матеріалу з різних навчальних предметів, а саме: на математиці учні вчаться розв'язувати задачі про дерева, розташовувати їх у порядку зростання та спадання, моделювати дерева 3 геометричних фігур; на українській мові учні вчаться правопису різних назв дерев, розбору слів за будовою, складанню усних розповідей та описів дерев, розгадуванню анаграм, загадок, ребусів, кросвордів; на українській літературі учні читають оповідання, вірші, казки про дерева, вчать вірші на пам'ять, складають власні казки про дерева; на образотворчому мистецтві учні вчаться малювати дерева, виготовляти аплікації; на основах здоров'я учні вивчають правила поведінки в лісі, корисні властивості дерев, їх використання в житті людини; на трудовому навчанні учні збирають гербарій та виготовляють саморобки 3 нього, висаджують дерева на шкільному подвір'ї, вчаться за ними доглядати.

Наведений вище тематичний проект може відбуватися як за горизонтальною, так і вертикальною інтеграцією, оскільки він охоплює багато навчальних дисциплін. За діяльністю він дослідницький, інформаційний, творчий та практичний; за кількістю навчальних предметів - міжпредметний; за кількістю учасників проекту - груповий та колективний; за характером контактів - внутрішній (в рамках одного класу); за тривалістю - короткостроковий (до одного тижня); за характером партнерських взаємодій кооперативний.

Розглянемо характерні особливості організації процесу навчання в системі професійної освіти в умовах сьогодення та можливості застосування інтегрованого проектно-тематичного навчання в закладах професійної освіти в процесі підготовки кваліфікованих робітників.

Характерною особливістю навчання в закладах професійної освіти є те, що учні не тільки опановують певні теоретичні знання, а й практичні уміння та навички в рамках конкретної спеціальності. Відбувається це на виробничому навчанні, що виконує в освітньому процесі інтеграційну функцію, оскільки дозволяє застосувати всі отримані при вивченні теоретичних дисциплін знання на практиці.

Традиційно процес навчання в системі професійної освіти передбачає чередування вивчення теоретичних дисциплін 3 виробничим навчанням. Тобто спочатку формуються знання, а потім вони закріплюються на практиці.

Поява нових Державних стандартів професійної освіти заснованих на компетентнісному підході дає змогу переглянути процес організації навчання в закладах професійної освіти. Якщо стандарти першого покоління чітко визначали перелік дисциплін, тем та час на їх вивчення з кожної конкретної професії певного кваліфікаційного рівня, то стандарти нового покоління визначають перелік компетентностей, якими повинні оволодіти учні, загальну кількість часу на їх навчання та його розподіл на різні види підготовки. Задача кожного закладу професійної освіти визначитися 3 переліком навчальних дисциплін, тем, розподілити час на їх вивчення. Питання вибору форм, методів та засобів навчання вирішується кожним педагогом самостійно.

Новою формою організації навчального процесу в системі професійної освіти на сьогодні $\epsilon$ дуальне навчання, що передбачає системне й органічне поєднання на умовах партнерства двох основних його складових: теоретичної (навчальної) складової, яку забезпечує навчальний заклад, та прикладної (практичної), яка забезпечується підприємством (потенційним роботодавцем) [4].

Дуальне навчання передбачає розробку навчального плану підготовки кваліфікованих робітників спільно 3 роботодавцем, на підприємстві якого буде відбуватися практичне навчання. Пошуком таких підприємств-партнерів заклад професійної освіти займається самостійно.

Але 3 огляду на зміст стандартів нового покоління (зокрема швейного профілю) не завжди можна знайти підприємства, які б дозволили реалізувати практичну складову, враховуючи асортимент продукції передбачений для практичного виконання стандартом та асортимент продукції, що виготовляє підприємство. Крім того, переважна більшість швейних підприємств $\epsilon$ приватними, діяльність яких спрямована на отримання прибутку від продукції, що виготовляється.

На сьогодні існує багато наукових досліджень та практичних прикладів застосування інтегрованого навчання в системі освіти взагалі та професійної зокрема. В науковому дослідженні І.Я. Пастирської [8] систематизована інформація стосовно інтегративних процесів в освіті України з 1980-го по 2000 рік, що відбувалися в різних типах навчальних закладів. 3 кінця 90-х років минулого сторіччя розпочався етап детального конструювання систем навчання на основі інтеграції знань та визначення загальнодидактичних підходів до побудови їх цілей, змісту, принципів, методів та засобів.

Одним 3 варіантів удосконалення форм організації освітнього процесу в системі професійної освіти на сьогодні $є$ застосування інтегрованого проектно-тематичного навчання. 


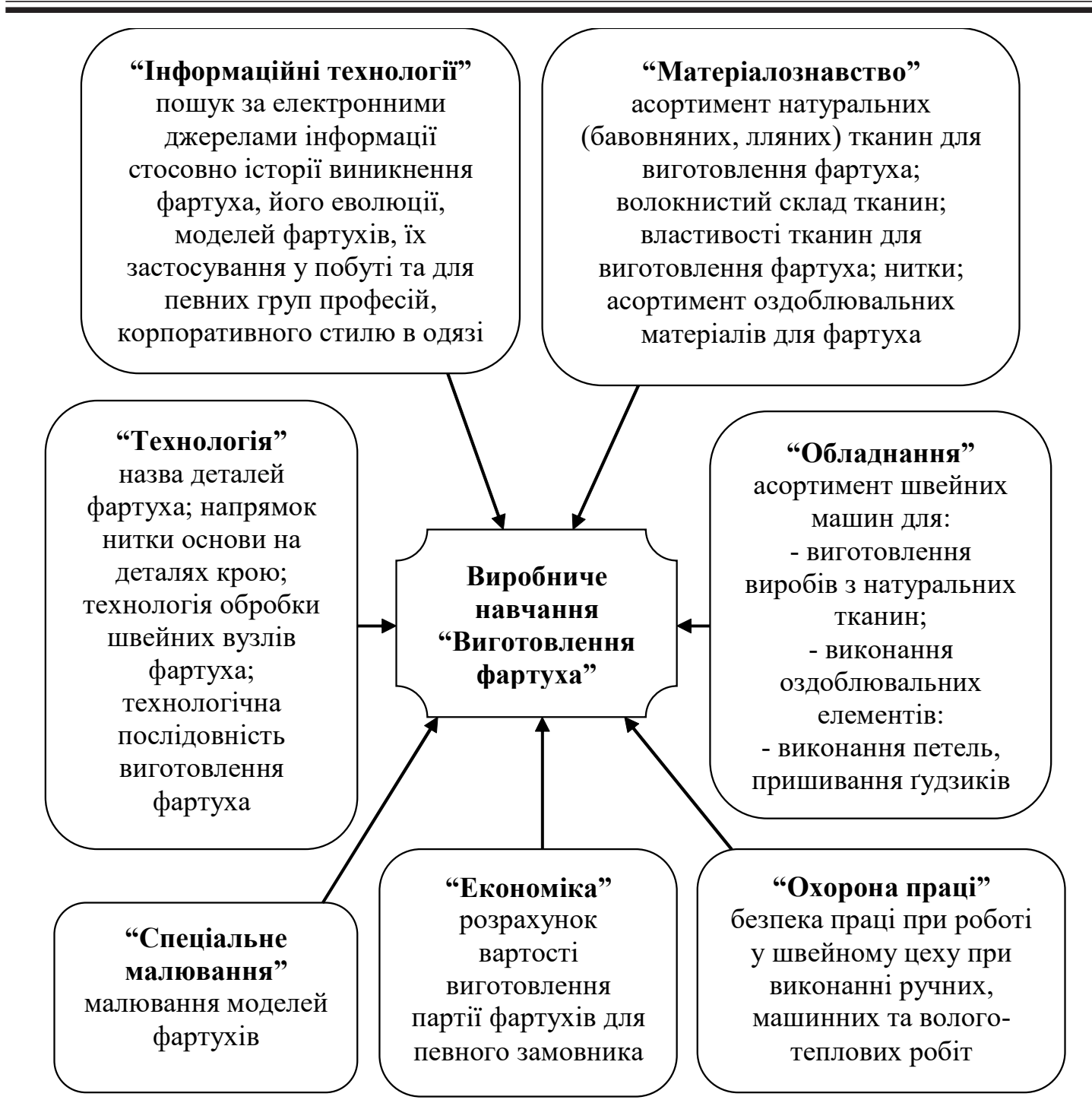

Рис.1. Схематичне зображення інтегрованого тематичного проекту "Виготовлення фартухів" при підготовці кваліфікованих робітників з професії “Кравець” 2 - 3 розряду в системі професійної освіти

За аналогією $з$ загальноосвітнім закладом наведемо стислий приклад інтегрованого тематичного проекту для закладу професійної освіти при підготовці кваліфікованих робітників 3 професії “Кравець” 2 - 3 розряду за стандартами нового покоління. Як було зазначено вище інтеграційну функцію в системі професійної освіти виконує виробниче навчання, яке (у випадку кваліфікованих робітників швейного профілю) пов'язане з виготовленням корисної продукції. Стандарти нового покоління для навчання за ними кваліфікованих робітників складаються 3 навчальних модулів, кожен 3 яких передбачає формування певної професійної профільної компетентності, однією 3 яких для кравця 2-3 розряду $\epsilon$ виготовлення фартухів. Тому інтегрований тематичний проект пропонуємо назвати “Виготовлення фартухів" схематичне зображення якого представлено на рис.1. На рисунку перелічені навчальні дисципліни інтеграцію змісту яких потрібно виконати при реалізації даного проекту. Кінцевим результатом повинен стати конкретний швейний виріб фартух. Завдяки інтеграції в проекті змісту навчального матеріалу пов'язаного саме 3 виготовленням фартуха учні повинні зрозуміти зв'язки між різними навчальними дисциплінами та реальним життям.

Наведений вище тематичний проект може відбуватися як за горизонтальною, так і вертикальною інтеграцією. За діяльністю він інформаційний, творчий та практичний; за кількістю навчальних предметів міжпредметний; за кількістю учасників проекту 


\section{ІНТЕГРОВАНЕ ПРОЕКТНО-ТЕМАТИЧНЕ НАВЧАННЯКВАЛФІКОВАНИХ РОБІТНИКІВ}

- груповий та колективний; за характером контактів - внутрішній (в рамках одної групи); за тривалістю - може бути короткостроковим (до одного тижня) або середньостроковим (два тижні та більше), це залежить від кількості годин відведених на виробничому навчанні на виготовлення конкретного виробу; за характером партнерських взаємодій - кооперативний.

Висновки. Впровадження в системі освіти України інтегрованого проектно-тематичного навчання дає змогу сформувати в учнів більш чітке розуміння кожного предмету в різних контекстах, будь-якої теми, завдяки i дослідженню через кілька точок зору; краще усвідомлення комплексного підходу, через який предмети, навички, ідеї та різні точки зору пов'язані з реальним світом; вдосконалити навички системного мислення.

\section{ЛIТЕРАТУРА}

1. Божко Н.В. Методика виробничого навчання майбутніх кравців у ПТНЗ засобами інтегрованих мікромодулів: автореф. дис. на здобуття наук. ступеня канд. пед. наук: спец. 13.00.02 “Теорія та методика професійної освіти” /Н.В.Божко. - Харків, 2010. - 23 с.

2. Волченкова Г.М. Проектно-тематичний підхід до навчання дітей початкової школи: [Міжнар. освіт. проект “Крок за кроком" для дітей від 6 до 10 років] / Г. М. Волченкова // Метод проектів: традиції, перспективи, життєві результати: Практико зорієнт. зб. / Ліцей міжнар. відносин № 51 м. Києва та ін.; Наук. кер. і ред. І. Г. Срмаков. - К., 2003. - С. 164-171.

3. Выготский Л.С. Психология развития ребенка / Л.С. Выготский. - М.: Смысл, Эксмо, 2004. - 512c.

4. Дернова М.Г. Дуальна модель вищої професійної освіти дорослих: Європейський досвід. / М. Г. Дернова // Освіта дорослих : теорія, досвід, перспективи. Випуск 2 (9) 2014. - Вип.2.-С.137-145.

5. Інтегроване навчання: тематичний і діяльнісний підходи (частина 2) [Електронний ресурс]: Режим доступу: http://nus.org.ua/articles/integrovanenavchannya-tematychnyi-i-diyalnisnyi-pidhodychastyna-2/

6. Любчак Н.М. Проектні технології: сутність та особливості використання у навчальному процесі / Н. М. Любчак // Вісник. Серія: Педагогічні науки. - К. : 2014. - Вип. 122. - С.144-150.

7. Нова українська школа: концептуальні засади реформування середньої школи [Електронний ресурс]: Режим доступу: https://www.kmu.gov.ua/storage/app/ media/reforms/ukrainska-shkola-compressed.pdf

8. Пастирська І.Я. Інтеграція змісту предметів природничого i гуманітарного циклів як загальнопедагогічна проблема (кінець XX - початок XXI століття): автореф. дис. на здобуття наук. ступеня канд. пед. наук: спец. 13.00.01 “Загальна педагогіка та історія педагогіки”/ І.Я.Пастирська. - Ужгород, 2012. -20 с.

9. Пиаже Ж. Избранные психологические труды / Ж.Пиаже. - М.: Междунар. пед. акад. - 1994. - 272 с.
10. Томина Е.Ф. Педагогические идеи Джона Дьюи: история и современность / Е. Ф. Томина // Вестник ОГУ. -2011. - №2 (121). - С.360-366.

\section{REFERENCES}

1. Bozhko, N. V. (2010). Metodyka vyrobnychoho navchannia maibutnikh kravtsiv u PTNZ zasobamy intehrovanykh mikromoduliv [Methodology of production training of future tailors in the vocational school by means of integrated micro-modules]. Extended abstract of candidate's thesis. Kharkiv, 23 p. [in Ukrainian].

2. Volchenkova, H. M. (2003). Proektno-tematychnyi pidkhid do navchannia ditei pochatkovoi shkoly: [ProjectThematic Approach to Primary School Children Education: International education Step by Step project for children aged 6 to 10 years]. Project Method: traditions, prospects, life results: Practical Guide. col. Lyceum Intern. relations No. 51 of Kyiv and others; Science manager and (Ed.). I.G. Ermakov Kyiv, pp. 164-171. [in Ukrainian].

3. Vygotskiy, L. S. (2004). Psikhologiya razvitiya rebenka [Child developmental psychology]. Moscov: Smysl. Eksmo, 512 p. [in Russian].

4. Dernova, M. H. (2014). Dualna model vyshchoi profesiinoi osvity doroslykh: Yevropeiskyi dosvid [The Dual Model of Higher Professional Education for Adults: A European Experience]. Adult Education: Theory, Experience, Perspectives. Vol. 2(9);Vol.2, pp.137-145. [in Ukrainian].

5. Intehrovane navchannia: tematychnyi i diialnisnyi pidkhody (chastyna 2) [Integrated Learning: Thematic and Activity Approaches (Part 2)]. [Electronic resource]. Available at: http://nus.org.ua/articles/integrovanenavchannya-tematychnyj-i-diyalnisnyj-pidhodychastyna-2/ [in Ukrainian].

6. Liubchak, N. M. (2014). Proektni tekhnolohii: sutnist ta osoblyvosti vykorystannia u navchalnomu protsesi [Design technologies: the essence and peculiarities of use in the educational process]. Herald. Series: Pedagogical Sciences. Kyiv, Vol. 122, pp.144-150. [in Ukrainian].

7. Nova ukrainska shkola: kontseptualni zasady reformuvannia serednoi shkoly [New Ukrainian School: Conceptual Principles of Reforming High School]. [Electronic resource]. Available at: https:// www.kmu.gov.ua/storage/app/media/reforms/ukrainskashkola-compressed.pdf[in Ukrainian].

8. Pastyrska, I. Ia. (2012). Intehratsiia zmistu predmetiv pryrodnychoho i humanitarnoho tsykliv yak zahalnopedahohichna problema (kinets XX - pochatok XXI stolittia) [Integration of the content of subjects of natural and humanitarian cycles as a general pedagogical problem (the end of the XX - the beginning of the XXI century]. Extended abstract of candidate's thesis. Uzhhorod, 20p. [in Ukrainian].

9. Piazhe, Zh. (1994). Izbrannyye psikhologicheskiye trudy [Selected psychological works]. Moscov: Mezhdunar. ped. akad., 272 p. [in Russian].

10. Tomina, E. F. (2011). Pedagogicheskiye idei Dzhona Dyui: istoriya i sovremennost [Pedagogical ideas of John Dewey: history and modernity]. Bulletin of OGU. No. 2(121), pp.360-366. [in Russian].

Стаття надійшла до редакції 25.01.2019 